\title{
Spiritualism: A Source of Prevention from Fatal Pandemic
}

\author{
(A General Estimate) \\ Dr. Vanshree Godbole
}

Associate Professor, English, Govt. M. L. B. Girl's P. G. College, Indore, M.P., India

\begin{abstract}
Spiritualismis a life Spring of Indian Philosophy, Culture and Religion.Philosophy shows the cause for the inescapable experiences of sorrow and suffering that has engulfed mankind today. The period following the outbreak of fatal pandemic Covid -19 has become the age of disillusionment, chaos, disbelief , utter despair, loss, and disorder in an individual's life. Hinduism is the only religion that is universal, It is a revealed religion, the priceless truth discovered by intuitive spiritual experiences. Need of the hour is to understand the psychology of commonman, his social condition and to help them regain confidence that has shaken the whole human race.
\end{abstract}

Keywords - Spiritualism, disillusionment, fatal, despair, confidence.

Spiritualism is a life Spring of Indian Philosophy, Culture and Religion "Every human being is a potential spirit and represents, as has been well said, ahope of GOD and is not mere fortuitous concourse of episodes like the changing forms of clouds or patterns of a kalideoscope."(1) As we know that the literature is replete with the writings of Men, who are said to know the whole truth of Nature and Human existence. The solutions and explanations offered by Man ranges from simple superstitions to the most subtle Philosophical speculations. Philosophy shows the cause for the inescapable experiences of sorrow and suffering that has engulfed mankind today.

The period following the outbreak of fatal pandemic Covid -19 has become the age of disillusionment, chaos, disbelief , utter despair, loss, and disorder in an individual's life. After witnessing large scale massacre an individual has started asking simple fundamental questions: Is this $\mathrm{Be}, \mathrm{Be}$ all and end of All life ?That has forced people,particularly Indians to turn towards "Spiritualism", the reason behind that India standing intact and integrated even after she had witnessed so many invasions, upheavals and natural calamity. This phase will pass on is the firm belief that's being generated.

Indian philosophy has been intellectual product of two innate human urge-reason and vision, it is an attempt to conceive world logically, a sincere endeavour to see reality face to face, by the inner concentration of Man, to contemplate the ultimate reality in terms of Globalisation.
The unrest of the age and passion for reform and solution to the present day up- rootedness of human race can be traced in Indian Philosophical system, that includes whole of mankind from all walks of life whether cultured, ignorant or learned. To quote Dr.Radhakrishnn "Religion from the beginning, is the bearer of human culture. It is the deepest kind of life reflecting the different phases complex and conflicting of human living."(2)Hinduism is the only religion that is universal, it is based on the spiritual experiences gained by ancient Rishis and Sages of India for the betterment of human race. Hindu religion is a revealed religion, the priceless truth discovered by intuitive spiritual experiences. A Hindu is not merely a Man, a name, Hindu is not only of Geographical, but of National and Racial importance. It's The Pity, Nobility, Generosity, Philosophy, and religious bent of Mind, Tolerance, Wisdom, Devotion, Renunciation, Self-Realisation, Ahimsa, Truth, and Purity are the traits that are associated with A HINDU. India has undergone severe hardships, has faced fierce battles and cruelties and Yet they live today, some mysterious power, some invisible force has given her strength and has protected her and will protect her today from this deadly attack on human race, is a firm belief.

The written document of the spiritual experience gained by ancestors is compiled inthe four Vedas, the Upanishads and the Bhagwat Gita. All the religions of the world have sprung from these sacred scriptures.Ayurveda is five thousand years old, a system of natural healing; the core of treatment is to encourage balance of physical mental and 
emotional body by following the right thinking, diet and ideal lifestyle.The basic theory of Ayurveda is to strengthen the self defence system of the body. All over the world emphasis is laid on alternate therapy of Ayurveda to fight with this deadly virus attack. The decoction made to drink is the combination of various herbs.

Optimistic approach towards life is the core of Indian Philosophy. Need of the hour is to understand the psychology of commonman, his social condition and to help them to regain confidence that has shaken the whole human race. The sacred Bhagwad Gita has suggested and has set a principle of life. The Bhagwad Gita regards Man as a complex of intellect, emotion and action. It gives a wonderful message of Hope, Consolation, peace and above all "Divinity of Man.'It solves all the problems of life and gives fearlessness to everyone and lifts up individual from the depth of penury and misery to the height of immortality and eternal bliss. Wehave perform certain ritual a step to throw this disease out was lighting lamps, blowing conches, clapping hands, all have some scientific explation of enhancing positivity that eventually will keep the moral uplifted. Constant practice of Pranayama and Meditation is suggested, another powerful therapy to cure from this disease. This theory runs parallel along with Ayurveda. To Quote The Bhagwad Gita verse that has preachings regarding yoga, rituals and the ultimate reality of God:-

The BhagwadGita Chapter 9. Verse 16-17

\section{अहुं क्रतुरहं यज्ञ: स्वधाहमहमौषधम्|}

मन्त्रोऽहमहमेवाज्यमहमग्रिरहं हुतम् $\|16\|$

पिताहमस्य जगतो माता धाता पितामहः।

वेद्यं पवित्रमोड़कर ऋक्साम यजुरेव च\|17\|

ahaṁkraturahaminajñahsvadhāhamahamaușhadham

mantro 'ham ahamevājyamahamagnirahaìhutam

pitāhamasyajagatomātādhātāpitāmahah

vedyamipavitramomkārariksāmayajureva cha

\section{Translation}

BG 9.16-17: It is I who am the Vedic ritual, I am the sacrifice, and I am the oblation

Offered to the ancestors. I am the medicinal herb, and I am the Vedic mantra. I am

the clarified butter, I am the fire and the act of offering. Of this universe, I am the Father;

I am also the Mother, the Sustainer, and the Grandsire. I am the purifier, the goal of knowledge, the sacred syllable. Om. I am the Rig Veda, Sāma Veda, and the Yajur Veda.

Against pessimism (3)

तंविद्याद्दुः खसंयोगवियोगयोगसज्ञितम्

सनिश्चयेनयोक्तव्योयोगोडनिर्विणणचेतसा| 23||

tam்vidyādduḥhha-sanyoga-viyogaimyogasañjñitam saniśhchayenayoktavyoyogo 'nirviṇna-chetasā

Translation

BG 6.23: That state of severance from union with misery is known as Yog. This Yoga should be resolutely practiced with determination free from pessimism.(4)

The Aspects of Hinduism suggested to be followed to reestablish human race:-

1 Dharma:- That includes whole world, the eternal Divine law of the God. Principles of Unity, anything that helps to unite all and develops universal brotherhood.Selfregulation of daily life.

2 Ethics: - That includes conduct and character. Ethics is related to Man and surroundings. A Man following the doctrines of ethics will not deviate from Dharma

3 Philosophic Traits: - Law of Karma. Any deed any thought that causes an effect is called Karma: An action produces effect.Thinking is Mental Karma which should be positive. Following the thumb rule every action has equal and opposite reaction.

4 Rituals: - In continuation with action rituals are performed to surrender to God for all evil action done that is sin. To pray to God to Forgive. Byprayers, going to temples, worshipping daily, chanting mantras.All these actions are meant to discipline oneself discipline our bodies preparing further for Yoga.

5Yog:- BhaktiYog, KarmaYog, Raj Yog and GyanYog. Various paths to reach God and attain salvation.

6 Various Sects:- various religion, to follow for communion withGod, the ultimate Goal of Human beings.

7 Mythology and Symbols:-The sublime and abstract philosophical ideas are taken to the heart of masses through impressive stories. The ideas are made highly interesting and are written and told in such a manner that hold the interest of masses without losing the grip of moral to be 
followed. The myths, parables, folk tales, allegories, are forms in which the ideas are narrated. As the Scripters of The Ramayana and The Mahabharata, are told accompanied with music, folk tales with morals that definitely appeals the crowd even today. During the period of locked down re-telecast of such legendary serials has definitely helped to hold the crowd back in their homes.

As said by Dr Radhakrishnann “ Relegion alone can give assurance and wider reference to ethics and a new meaning to human life...........It is the core of all being , the inner thread by being string on which the whole world exist."(5)

With the positive step humans must proceed towards victory, victory over the enemy,the unseen invader, The Bhagwad Gita`s concluding verse of last chapter gives a message with a deep pronouncement that there can be only one verdict in this War- Victory will always be on the side of God and his pure devotee and so will goodness, supremacy, and abundance.

\section{The Bhagwad Gita Chapter 18-verse 78}

\section{यत्र योगेश्वर: कृष्णो यत्र पार्थो धनुर्धरः। तत्र श्रीर्विजयो भूतिध्रुवा नीतिर्मतिर्मम || 78\|}

yatra yogeśhvarah kriṣhṇo yatra pārtho dhanur-dharạ̣ tatra śhrīrvijayo bhūtirdhruvā nītirmatir mama

Translation

BG 18.78: Wherever there is Shree Krishna, the Lord of all Yog, and wherever there is Arjun, the supreme archer, there will also certainly be unending opulence, victory, prosperity, and righteousness. Of this, I am certain. (6)

\section{REFERENCES}

[1] Radhakrishnann S. :Eastern Religionsand Western Thought. pp83, Oxford university Press, 1989.

[2] Ibid pp116

[3] www.holy- bhagwad-gita.org.

[4] Ibid

[5] Radhakrishnann S. : Eastern Religions and Western Thought. pp83, Oxford university Press ,1989.

[6] www.holy- bhagwad-gita.org. 